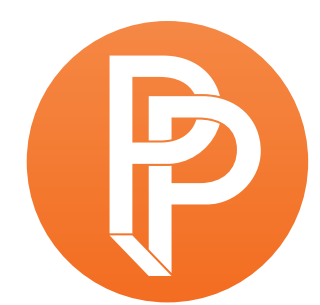

PERFORMANCE

PHILOSOPHY

\title{
ANARCHIC REFLECTION AND THE CRISIS OF KRISIS: WORKING WITHARTAUD
}

\author{
JOEL WHITE KING'S COLLEGE LONDON
}

There is also the itch to use this power [self-consciousness] for trifling, and thereafter to trifle methodically and even by concepts alone, i.e., to philosophize; and then also to grate polemically upon others with one's philosophy, i.e., to dispute, and since this does not readily happen without emotion, to squabble on behalf of one's philosophy, and finally, united in masses against one another (school against school, as contending armies) to wage open warfare; this itch, I say, or rather drive, will have to be viewed as one of the beneficent and wise arrangements of Nature, whereby she seeks to protect man from the great misfortune of decaying in the living flesh.

Immanuel Kant (2002), 435

It certainly seems wherever simplicity and order reign, there can be no drama or theatre and that true theatre, just like poetry but by other means, is born from organised anarchy, after philosophical struggle, which is the passionate aspect of these primitive unifications.

Antonin Artaud (1974), 49 
Several years ago, I began reading Artaud's Euvres complètes and compiling a document of all his explicit and implicit references to philosophical and literary works. Once complete, the idea was to situate Artaud as a thinker in his own right, rather than simply a playwright and maddened poet. I would do this by schematically connecting his aesthetic, philosophical and political projects into what Artaud called a 'formal anarchy' (Artaud 1974, 54). An oft-repeated principle of reflection led this research-il faut tout lire d'Artaud [one must read all of Artaud] - which became the mantra of my own practical madness. This il faut tout lire was not to be a demand qualified by a pre-given end: an il faut tout lire in order to critically understand Artaud, or an il faut tout lire in order to diagnose him clinically. It was an il faut tout lire unconditioned, as far as possible, by the telos of the critical or the clinical domain. The purpose, other than to reproduce my own life through research grants, was to read Artaud philosophically, without the prejudice of exegesis necessitating a strict allegiance to any party line.

However, this principle, and the philosophico-reflective means used to carry out its demand, seemed to lead to a proliferation of 'privileged enemies', a term which I borrow from Derrida's 1996 MoMA conference, where he used it in reference to Artaud:

\begin{abstract}
I thought it incumbent on me, however, to situate here, if only in a few words, the front, a sort of incessant war that, like antipathy itself, makes Artaud for me into a sort of privileged enemy, a painful enemy that I carry and prefer within myself, at closest proximity to all the limits against which I am thrown by the work of my life and death. (Derrida 2017, 7)
\end{abstract}

Philologically, Derrida's testimony to an incessant war reads much like Artaud's own declaration of war against Marx made during his 1936 Mexican conferences and later collected under the title Messages révolutionnaires: 'All creation is an act of war, a war against hunger, against nature, against sickness, against death, against life, against fate [...] There is a war between Marxism and myself, and this war rests on a distinct notion of what individual consciousness is' (Artaud 2007, 141). Placing the particularity of these two wars of resistance to one side-the one concerned with Artaud's sublimity the other with Marxist epistemological determinism-we can discern, in the invocation of their 'privileged enemies', a form of creative polemics in both Artaud and Derrida's writing. This creative polemics, which in many ways is a mode of working with (as opposed to working on) such a privileged enemy, functions to produce the necessary resistance against which the actuality of thought, or even life, can reorganise itself As Artaud writes in true Heraclitean style, 'creation' is an act of war against hunger and death: against fate. While I would not exclude Artaud and Derrida from my list of privileged enemies (I hold them both at the limit of my own life-work), they are not the adversaries that I wish to discuss in this autobiographical introduction. Instead, these adversaries are located in two different discourses that have, in their own way, taken issue with my philosophical reading of Artaud: two fated traditions with which I have found myself at war.

Within the traditions of French studies and performance studies, to recover a philosophy from Artaud's work, or even to read Artaud in relation to the history of philosophy, is regularly seen to constitute-in the words of a recent reviewer of my project-the very 'loss of l'esprit d'Artaud'. I was, 
by sleight of hand, to be responsible for the desertion Artaud's esprit; philosophy was to be my dark art. Yet this charge followed the failed attempt at writing on Artaud from within a philosophy department, the tradition in which I was my formally trained. According to one of the guardians of this domain, to work on Artaud as a philosopher would not be 'philosophical' enough for a philosophy department. The borders and limits of philosophy were to be protected from the esprit of Artaud-the same esprit that was fetishised and safeguarded by those on the other side of the trench. Rejected from one tradition (philosophy), scorned by another (French studies), I felt besieged on all sides. But what did they mean, these privileged enemies of mine, by l'esprit d'Artaud? Why was philosophy protecting itself from Artaud, and why was Artaud being protected from philosophy?

Although these questions have never been overtly posed to either of the two camps, it does not require much insight to attempt an answer. The esprit of Artaud is nothing other than the unquestionable status of his 'madness'. Artaud is 'mad'. Madness is here an analytical predicate judged determinate by those in their departmental fields. To be clear, by 'madness', I do not mean Artaud's experience of psychosis or the physical and psychological suffering that he endured, in and out of different asylums, throughout his life. 'Madness,' for those that employ this term both in and outside an academic context, very rarely has much to do with actual mental distress. Instead, I use it to refer to the predicative means by which the inside of an academic tradition protects itself from the outside. With Artaud, philosophy risked opening its doors to 'madness', and 'madness' was at risk of being philosophised. As Howard Caygill so elegantly puts it, this logic of the inside and outside of the academy reveals a type of 'Artaud-immunity', whereby Artaud's work is either entirely rejected, or it is let in on the grounds that his 'madness' is acknowledged $(2015,15)$.

One of the more recent and widely read books on Artaud is Sylvère Lotringer's Mad like Artaud. Published in 2003, Lotringer interviews Jacques Latrémolière, Gaston Ferdière, two of Artaud's former psychiatrists, as well as Paule Thévenin, the editor of Artaud's Fuvres complètes. Lotringer's thesis suggests that those affected by Artaud's life and work are, or become, 'mad' like him. On this point, I will leave it to the words of Paule Thévenin who, when interviewed, bluntly refuses to fall for Lotringer's game:

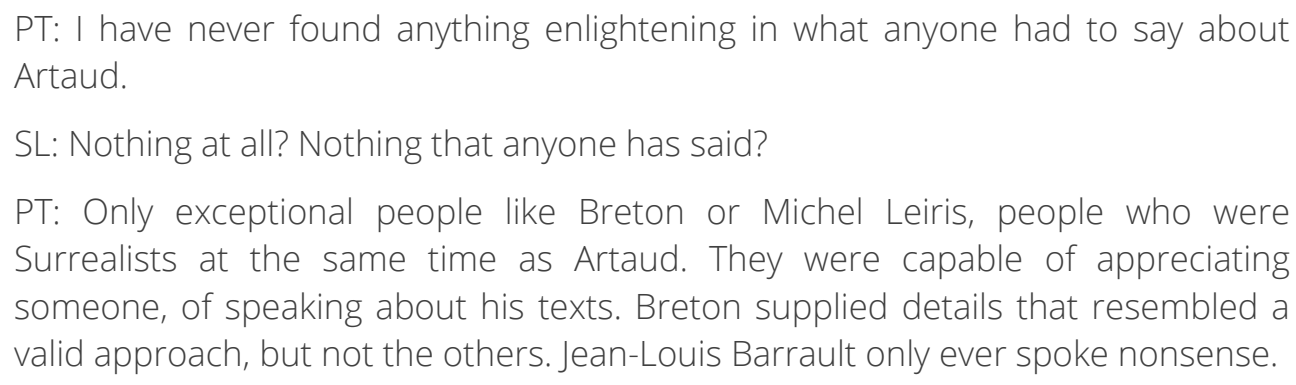

(Lotringer 2015, 200)

Nonsense, then: Lotringer, like Barrault before him, is speaking nonsense. Rather than being capable of appreciating Artaud-rather than speaking about his texts for themselves and on their own merits-Lotringer writes about his 'madness'. ${ }^{1}$ The reason for this is arguably also why a lot 
of the secondary literature on Artaud is biographical in nature. ${ }^{2}$ In the face of working with Artaud, it is much easier to recount how he took peyote in Sierra Tarahumara, or to muse over why he was arrested in Ireland. ${ }^{3}$ The logic is straightforward: to say that Artaud reasoned is mad, and to say that he is mad is reasoned. The consequences of this are that Artaud and others, such as Hölderlin, Nietzsche, Baudelaire and Nerval, become recognisable only through the maddened category of the non-category. When translated into Artaud's French, this could be called la catégorie forcenée de la non-catégorie: a category forced into the maddened [forcenée] category of the non-category. This critical strategy of the non-category is often employed in the introduction to pieces of writing on Artaud. Take, for example, Phillipe Sollers's more recent elegy to Saint Artaud:

\begin{abstract}
A poet? Yes, a great one, but this word covers little ground. A thinker? Yes, fundamentally, but no philosopher would truly know how to reckon with Artaud (and even less so an academic). A negative theologian? An understatement, since for Artaud, nothing is either ideal or abstract. A specialist of myths and shamanic rituals? His personal experience (notably in Mexico) proves it. A druggie? He never managed to finish with the opium that eased his suffering. A madman? If that reassures you. (Sollers 2011, 406)
\end{abstract}

Sollers does not explicitly judge Artaud as non-categorisable, or judge that his work 'refuses categorisation', as others have more recently (Murray 2014, 7). However, it is of little surprise that at the end of this introductory list of possible (but at the same time impossible) critical/clinical categories, the usual suspects of the non-category are then listed: 'Gérard de Nerval, Edgar Poe, Baudelaire, Lauréamont, Rimbaud, Nietzsche' (Sollers 2011, 406). To argue for the impossibility of categorisation assumes that the work of others is categorisable. It places Artaud, and his 'madness', into the tragic category of the non-category. Madness, in whatever form, is therefore never actually the outside, but rather the category against which rationality secures itself, something Paul Preciado, who delves into the pharmacological intricacies of exclusion, calls an 'inclusionary exclusion' (Preciado 2013, 183). Without madness, rationality's power would collapse. Madness is rationality's frame, its autobiographical introductory remark.

Preciado's notion of the 'inclusionary exclusion', a notion that includes/excludes other categories such as 'deviants', might be read as a development of the polemic that took place between Foucault and Derrida regarding Derrida's 1963 essay 'Cogito and the History of Madness', an essay that was a reply to Foucault's 1961 book Madness and Civilization: A History of Insanity in the Age of Reason (2006). This polemic, which Derrida called a crisis between Master and disciple (a disciple with an 'unhappy consciousness'), can be summarised as a dispute over the distinction or separation between the logos and its contrary, madness/silence (Derrida 2017, 36). More specifically, the polemic concerned whether or not the Cartesian cogito excludes or includes madness.

With Foucault, I want to argue in this article that the category of the non-category of madness is maintained for questions of power. However, the disequilibria of power between the rational and the irrational are upheld not because the nature of experience is entirely different in each-to agree with Derrida's reading of Descartes, 'Whether I am mad or not, Cogito, sum'-but because one mode of experience positively defines by means of the exclusion of another (Derrida 2017, 36). 
The non-category that gathers the non-categorisable into its category gathers nonetheless. It is a category produced by the pathological anxiety of the rational - the anxiety of the normopaths. Madmen, after all, must confess to being mad before they are judged harmless enough to cross the border of the non-category, back into the categorisable.

When judgment and not the judgeable undergoes criticism, as it does here, does it enter a crisis, or indeed, a krisis (kpíø/c/krisis in ancient Greek means decision or judgment)? Does this constitute the critical point when judgment is no longer possible, or where the absence of the possibility of judgement constitutes judgment itself, i.e. I judge that it is impossible to judge? Both, perhaps. When the categorical nature of judgment opens itself up to the non-categorical, it becomes apparent that the capacity to judge was always already maintained by the outside of the judgeable. This movement toward the non-categorical is, therefore, not without its epistemological consequences. To judge anything as non-categorical paradoxically produces a list of all those things that are impossible to categorise: another category. The outside of judgment becomes folded back into the inside of judgment by the negation of the possibility to judge. A crisis in and of krisis reveals its scandalous underbelly. Nonetheless, the crisis of krisis, or the krisis of crisis, should not give rise to apathetic nihilism, nor should it give rise to the all too familiar obsession over the limit itself. The particular thinkers who are subsumed into this maddened category of the non-category should not merely pose 'as signposts to future work'; as Foucault writes in his 1970 inaugural speech at the Collège de France, as oracles to a new world order (Foucault 2001, 152). Perhaps it would only suffice to work a little closer with those that are gathered into this noncategory, to actually work with Artaud, not just write on him, or indeed 'as him' as Roland Barthes insists (Barthes 1995, 63, my emphasis).

To work with Artaud, to reflect with him, one needs the space in which to do it. To Esa Kirkkopelto's question from the first issue of Performance Philosophy, 'for what do we need performance philosophy?' (Kirkkopelto 2015), the following answer can be given: Performance Philosophy, both as an academic journal and as a field of study, is needed so that those that find themselves forced into a disciplinary no man's land may develop a community of their own-a common front. Performance Philosophy constitutes a community wherein Artaud, qua philosopher that performs and performer that philosophises, will not be prejudged or categorically determined. It is a space in which it is possible to work with Artaud; to argue, as this article does, that when Artaud writes of the 'function' of the Theatre of Cruelty, he is conceiving of a theatre that performs or that acts philosophically, and not as a mere analogy to philosophy.

The rest of this article explores how this 'function' operates philosophically. It argues that the 'function' of the Theatre of Cruelty (the way in which it performs) is through what I term anarchic reflection. This mode of reflection is defined as an unintentional and/or intentional (cruel) crisis of the judgment of Form that opens the possibility of Form's transformation. To show how the Theatre of Cruelty performs anarchic reflection, this article works with the Kantian distinction between determining and reflective judgment found in The Critique of Judgment. It will extend reflective judgment, via Artaud's work on 'anarchic destruction', 'anarchic poetry' and the energetic notion of entropy (the physical consequence of the second law of thermodynamics) into anarchic 
reflection. While Kant is often read as a rational philosopher, Kant's philosophical project is one of the critique of pure Reason, that is, the delineation of the limits of judgment or of the crisis of krisis of pure Reason. Kant's third Critique and the elucidation of aesthetic reflective judgments, such as the judgment of the sublime, are exemplary of this-here, judgment is pushed to its critical limit. If Kant's critique of judgment is a model of how the crisis of krisis operates philosophically, and if we are to understand better how the Theatre of Cruelty functions as a cruel crisis of the krisis of Form, then it is necessary to read Kant with Artaud. ${ }^{4}$

In the 'technique' section of the first published manifesto for the Theatre of Cruelty (1932), Artaud specifies that the notion of 'function' in the 'true sense of the word' should be employed to understand how the Theatre of Cruelty 'acts' (Artaud 1974, 70). The word 'function' derives from the Latin fungor, meaning to perform a vital task, either organically or mechanically. Both organs and components perform the task of keeping the organism or technical object alive or operational. How an organ or a component functions is, therefore, intimately related to its vital or operational task (how it 'acts'). To ask how the Theatre of Cruelty functions is, thus, to ask of its task. The transition from the what question of ontology to the how question of 'function' undermines any rigid ontological demand made of the Theatre of Cruelty.

Further into the 'technique' section, Artaud defines the task the Theatre of Cruelty as 'anarchic destruction' (Artaud 1974, 70). The task of 'anarchic destruction', he writes, is 'to organically call into question [remettre en cause] man, and his ideas on reality [réalité] and his poetic position in reality [réalité]' (Artaud 1974, 70). If anarchic destruction is the task of the Theatre of Cruelty, then anarchic reflection is how it happens (its functioning). Since 'reality' is called into question in the Theatre of Cruelty, it is crucial to elucidate what reality [réalité] might mean and to clarify how anarchic destruction is effectuated by anarchic reflection.

To conceptually connect anarchic destruction qua task and anarchic reflection qua function of the Theatre of Cruelty to Kant's reflective judgment, réalité in Artaud will be understood as the English 'actuality'. Whereas actuality and reality in English are conceptually and philosophically distinguished, the translation of Kant's Wirklichkeit (the actuality with which reflective judgment reflects) into French was, until more recently, translated as réalité (perhaps because actualité is more commonly understood as something akin to 'current affairs'). ${ }^{5}$ To confuse matters further, when philosophical French is translated into English, réalité is often calqued as 'reality', when it should arguably be translated as 'actuality'. The Wirk in Kant's Wirk-lichkeit, which etymologically shares a root with the English 'work', is the German translation of the prefix act in the Latin word

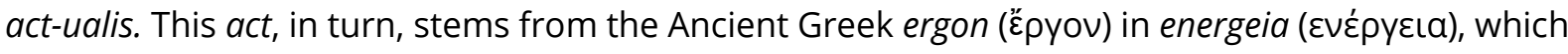
means 'to work'. Wirk, act, and ergon all signify the notion of that which 'acts' or is 'at work', as distinct from that which is 'truly real' or 'really true'.

Artaud is acutely aware of this philosophical problem of translation, perhaps both through his reading of Henri Bergson (who, like Gilles Deleuze after him, attempts to distinguish between the 
virtual and the actual, the possible and the real) and through his use of the French language. ${ }^{6}$ This is evident in the notes to the second manifesto of the Theatre of Cruelty (1933), where Artaud considers naming the Theatre of Cruelty 'a theatre of actuality [actualité]' due to the necessity for a theatre that 'acts' on the spectator. He stops short, however, because the expression 'le théâtre actuel' means 'current theatre' not 'actual theatre', in the sense of a theatre which 'acts [agit]', is 'in action [en action]' or 'actualises [actualise]' (Artaud 1978, 83). The absence in the French language of a more philosophically developed notion of actuality can also be felt in several key sections of Artaud's work with the Theatre of Cruelty. For example, when Artaud uses the word réel, as he does in the first manifesto, it is either distinguished from the virtuel (again, the Bergsonian resonances are clear, although this virtuel differs from Deleuze's) or qualified with the adverb activement (Artaud 1978, 89-90). Again, réalité, réel, and réaliser do not pertain to ontological veracity but to that which is at work, or actual, in the theatre. ${ }^{7}$ The Theatre of Cruelty is actualist, not realist. It is not true to life; it acts on life.

The reason why anarchic destruction and anarchic reflection bear a conceptual relation to Kant's reflective judgment -the reason why anarchic reflection is a modality of Kantian reflectioninvolves the way anarchic destruction takes place, by organically 'calling into question actuality [réalité] and man's position in actuality [réalité]' (70). Whereas Artaud writes 'organically call in to question [remettre en cause]' in the published first manifesto, one year later, in the notes to the second manifesto, he changes the phrasing to 'organically reflect' (Artaud 1978, 253). Artaud's notion of calling into question or reflecting is a destructive modality of reflection because it organically reflects with man's position in actuality, which elsewhere Artaud suggests has become ossified. Calling into question acts to destroy because it takes what is self-evident and reconsiders its necessity, breaking with the rigidity of prejudice. This connects to Kant's reflective judgment because reflective judgments, as will be argued, are reflections on 'given representations', and their point of departure is Wirklichkeit, or actuality.

The 'organic' nature of this reflection was said to relate to the notion of function-how an organ or a component functions vitally for the given organism or technical object. While the relation between organs or components might be understood mechanically (nexus effectivus-how they work together), the end that they serve is understood teleologically (nexus finalis-what they work for). Anarchic reflection is a destructive reflection that teleologically calls into question man's organic position in actuality. It anarchically destroys the mechanical and teleological position of man in actuality. Anarchy that wages war on teleology. In the notes to Artaud's first manifesto, further amendments to the sentence regarding 'anarchic destruction' and the function of the Theatre of Cruelty can be found. In the editions of Colette Allendy and M. Jean-Marie Conty, Artaud uses the term 'energetic destruction' instead of 'anarchic destruction', and 'energetically calls into question the constitution of man' instead of 'organically call into question' (Artaud 1978, 315). There would appear, therefore, to be important conceptual links to be made between reflection, destruction, anarchy, energy, man's organic constitution, and actuality.

The destructive principle that binds these notions together in/as the Theatre of Cruelty is not teleological but energetic and an-archic. It is the principle that is without-principle (an-archic). At 
the heart of anarchic reflection stands the principle of entropy, a principle that energetically describes the necessity and universality of nature's decay/destruction. The principle of entropy links the above notions together by reuniting the modal category of actuality (which, as mentioned above, is the English translation of Wirklichkeit, actualis, and energeia) and the entropic notion of

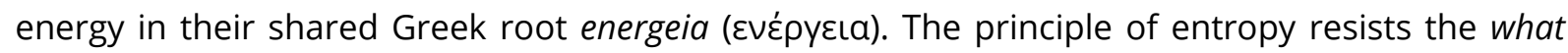
question of ontology and the why question of teleology by instead grounding life, thought and Form on the movement from order to disorder. It extends the modality of reflection from Kantian reflective judgment to anarchic reflection. However, before moving to a fuller explication of how the principle of entropy governs anarchic reflection, it will be necessary to outline how reflective judgment functions for Kant. Finally, and once a fuller explication of the function of anarchic reflection in/as the Theatre of Cruelty has been elucidated, I will conclude by showing how the counter-purposive nature of Kant's sublime and its reflection with actuality (energeia) performs, similar to Artaud, a crisis of krisis.

In the introductory frame above, the conception of the maddened category of the non-category opened the discussion of what occurs epistemologically when judgment is itself subject to judgment. The critical enterprise of Kant's The Critique of Judgment follows this path of judgment's crisis. After having secured the categorical a priori conditions for theoretical and practical judgments in the first two critiques, as well as the principles that serve the ends of these two forms of judgment, Kant then attempts to submit the power of judgment to its own critique. Although The Critique of Pure Reason claims that the secret of judgment's principle (which determines the way in which heterogeneous realms of intuitions and concepts become reunified schematically) would remain hidden in the 'depths of the human soul' (Kant 2009, 273), the third Critique opts to outline the entanglement of these depths. It describes how krisis enters crisis.

The outline of this crisis of krisis begins through an investigation into the difference between determining and reflective judgment, a difference marked by the possibility or impossibility of making categorical judgments about the beautiful, the sublime, and about life. Whereas determining judgments, as the name suggests, are analogical to categorical or theoretical judgments, reflective judgments critically explore the crisis of krisis-judgments that happen in the absence of the categorical certainty of the a priori table.

In the first introduction to the third Critique, Kant defines reflective judgment (reflektierende Urteilskraft) by distinguishing it from determining judgment (bestimmende Urteilskraft):

The power of judgment can be regarded either as a mere faculty for reflecting on a given representation, in accordance with a certain principle, for the sake of a concept that is thereby made possible, or as a faculty for determining an underlying concept through a given empirical representation. In the first case it is the reflecting, in the second case the determining power of judgment. To reflect (to consider [überlegen]), however, is to compare and to hold together given representations either with others or with one's faculty of cognition, in relation to a 
While determination and reflection are not entirely new notions for Kant's critical system, the division of judgment into either determining or reflective is. Determining judgment, for example, could be compared with several other theoretical forms of judgment that are subsumptive. These are, in other words, forms of judgment that subsume the given empirical representation (a particular) under a general concept that lies in the understanding a priori (a universal). Determining judgment (whether empirical, mathematical or transcendental) functions by 'departing' from a concept that is logically placed prior to the intuition. As Kant argues in the first Critique, this form of judgment is best understood proleptically: the understanding anticipates sensory intuitions before their reception. Counter to both empiricism and rational dogmatism, Kant applies this theory of understanding to the possibility of experience itself, arguing that experience is only possible due to the synthetic a priori judgments that take place before the reception of representations. With determining judgment, we are, therefore, still on safe and well-trodden ground. Not only is determining judgment a subsumptive judgement that securely reunite particulars with their universals, it is also regulated by strict principles, such as the principle of noncontradiction.

If determining judgment offers refuge, then reflective judgment puts us out to sea. The process of reflective judgment does not have the security of an underlying concept in the understanding by which the intuition can be subsumed. Instead, reflective judgment reflects on either a singular representation and provokes the feeling of the beautiful or the sublime or compares several representations for the sake of an empirical concept that is 'thereby made possible' (teleological judgment). Contrary to determining judgment, reflective judgment is not proleptic, but 'artistic' or 'technical' (Kant 2000, 17). Rather than anticipating particulars through concepts a priori, reflection moves from given representations to an indeterminate conceptual no man's land. The lack of a corresponding universal a priori seems to demand that one is formulated. As Michael Budd writes, 'in reflective judgement, you are aware of something and attempt to acquire a concept under which it can be brought' $(2008,106)$. Kant's attempt at outlining reflective judgment appears as both the search for the conditions of possibility of judgment as well as the production of its conceptual possibility. It defines a reflective relation with the world as it actually exists (Wirklichkeit). Instead of a realm of legitimised possibility or the speculative realm of pure Reason (God, the immortal soul, and absolute freedom), reflective judgment proceeds from the entangled and labyrinthine nature of actuality with which it is intricately interwoven.

As is usual with Kant, reflective judgment has central to it a particular/peculiar orienting regulative principle without which conceptualisation could not take place-without which one would be 'mad' lost in the tangled mess of actuality. This orienting principle functions as the milestone for the rest of the third Critique. As the following passage makes clear, this orienting principle is teleological in kind: 
The reflecting power of judgment thus proceeds with given appearances, in order to bring them under empirical concepts of determinate natural things, not schematically, but technically, not as it were merely mechanically, like an instrument, but artistically, in accordance with the general but at the same time indeterminate principle of a purposive arrangement of nature in a system, as it were for the benefit of our power of judgment, in the suitability of its particular laws (about which understanding has nothing to say) for the possibility of experience as a system, without which presupposition we could not hope to find our way in a labyrinth of the multiplicity of possible empirical particular laws. Thus, the power of judgment itself makes the technique of nature into the principle of its reflection $a$ priori, without however being able to explain this or determine it more precisely or having for this end an objective determining ground for the general concepts of nature (from a cognition of things in themselves), but only in order to be able to reflect in accordance with its own subjective law, in accordance with its need, but at the same time in accord with laws of nature in general. (Kant 2000,17)

This teleological principle, the 'purposive arrangement of nature in a system', is what Kant calls the 'heautonomous' (17) principle that reflective judgment sets itself. Unlike the autonomy of the understanding, whose laws are spontaneously applied to nature, heautonomy sets the laws as an orientating principle for the production and judgment of the judgment of nature. In this sense, it is schematically indirect and analogical: 'The power of judgment itself makes the technique of nature into the principle of its reflection a priori without, however, being able to explain this or determine it more precisely or having for this end an objective determining ground for the general concepts of nature' (17). What Kant reveals is twofold: that the peculiar principle of reflective judgment is indeterminate and ungrounded in any objective reality in concreto, and that this principle is regulative and subjective. In other words, the possibility of judging and conceptualising nature with systematic empirical concepts rests on an as if. It is possible to judge nature in relation to its technical or artistic purposiveness because it is as if nature is purposive and artistic, something that Paul Guyer calls the 'regulative ideal of systematicity' (Guyer 1990, 17).

This teleological but indeterminate regulative principle sets the stage for the further division of reflective judgment into aesthetic and teleological judgments, aesthetic judgments being those made regarding the feeling of beauty and sublimity, and teleological judgments regarding the internal and external purpose of organised beings. Both aesthetic judgments and teleological judgments are essential for the development of this article's central concept-anarchic reflectionand for understanding how it functions in/as Artaud's Theatre of Cruelty, since anarchic reflection is conceived of as an extension of Kantian sublimity qua a crisis of judgment.

Before moving to an explanation of how Kantian sublimity operates, I would like to interject by quoting Artaud from one of his 1947 notebooks used to prepare for his infamous Vieux-Colombier tête-à-tête. In this notebook, Artaud refers to both Kant and Spinoza by name, praising them for having interrogated the labyrinthine nature of the cerebral (Artaud 2003, 26). Whether coincidental 
to Artaud's reference to Kant or not, Artaud explicitly discusses notions of judgment (arguably scholastic), teleology (or the lack thereof), and, less explicitly, entropy. The following passage, written only pages before the reference to Kant, outlines Artaud's discussion of these interrelated terms. It is read with Kant's distinction between determining and reflective judgment in mind:

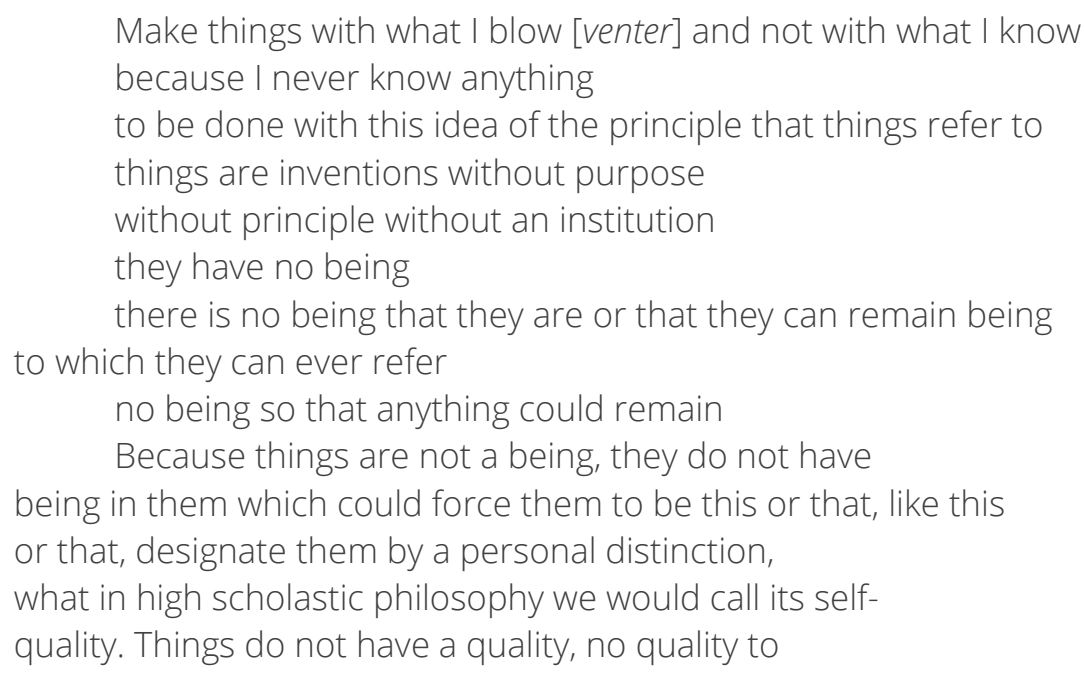

The graphic specificity of these two segments of writing points us toward the rejection of one principle of judgment (teleology) and the propaedeutic affirmation of another (entropy).

Firstly, Artaud unequivocally rejects the idea of a principle to which things refer so that their purpose (telos) can become manifest to the understanding: things are 'inventions without guiding purpose, without institution'. They do not possess an internal organised structure of being that grants things a 'self-quality'. This rejection of 'purpose' and 'self-quality' appears to be a reference to the scholastic notions of quiddity or haecceity, philosophical terms that are ontological precursors to Kant's more epistemological philosophy of judgment. Though often conceived as synonymous, quiddity (literally, 'whatness') designates the essential properties that particulars share with others in their genus: for example, all triangles 'have three sides'. Quiddity acts as the principle by which judgment is made of what something is - as Artaud writes, a 'self-quality'. 
Haecceity ('thisness'), on the other hand, defines the specific marks by which a particular thing is different to other particulars in its genus: for example, the lengths and angles of different triangles. Haecceity governs judgment regarding singularity: which triangle is this, and how is it this triangle? Whereas quiddity is related to theoretical subsumptive judgment (determining), haecceity is associated with the principle of individuation, the principle by which particulars individuate themselves within their genus. Haecceity is, therefore, much more concerned with the actuality of particulars. For instance, it could be argued that all chairs have the same teleological purpose and the corresponding Form that make them chairs. However, not all chairs are materially identical. They are either made from different pieces of the same material or from varied materials.

Artaud rejects both ontological and teleological quiddity and haecceity in the first segment. Of quiddity, he writes, 'things are inventions without purpose without principle [...] there is no being that they are or that they can remain being'. Of haecceity, he writes, 'things are not a being, they do not have being in them which could force them to be this or that, like this or that'; things do not have an ontological 'personal distinction'. However, whereas he rejects quiddity no matter its modality, he does not completely reject haecceity. As is more evident in the second segment of this passage (and later in the notebooks), an energetic principle by which things are formed and deformed without teleology or ontological personal distinctness (an 'I am') is affirmed by Artaud. However, by the end of the passage, Artaud discards a form of judgment that could determine what a thing is. Artaud considers any judging-through or judging-by (perjuger or parjuger) imbecilic. To put it into Kantian terms, Artaud appears to reject determinate judgment.

What follows this, however, offers something different. Artaud begins to elucidate his position concerning the judgment of things in relation to haecceity. Three affirmative statements of necessity point toward the elaboration of an entropic principle of individuation. Artaud writes: 'Things must pass away/Everything must pass away/Nothing can remain'. While all three of these statements are similar in content and partake of 'passing away', on closer inspection, they describe three different moments of deformation. The first is the inevitability that 'things' will pass away, the second is the inevitability that 'everything' will pass away, and the third is the affirmation that 'nothing can remain'. From the singular (things) to the general (everything), Artaud affirms that nothing will remain. Instead of retreating into the transcendent world of Being, Artaud transforms 'passing away' (or entropy) into the principle that governs particulars, genera, and totality alike. As will be argued, 'passing away' (deformation or entropy) acts as the principle of principles (arche)that which directs anarchic reflection.

It is important to note that Rudolf Clausius, one of the founders of thermodynamics, introduced

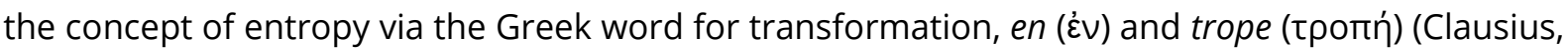
1867). The idea of entropy as the principle of transformation should, therefore, be held in mind in what follows. Further, while the definitions of entropy and the second law of thermodynamics are still open to clarifications, in my development of the notion of entropy I will accept Clausius's summary of the first two laws: (1) 'The energy of the universe is constant' and (2) 'The entropy of the universe tends to a maximum' (Clausius 1856, 98). The best way to grasp the actual consequences of these two laws is to think in terms of their mechanical or organic application. For instance, the 
internal energy chain in a steam engine transforms chemical energy into workable kinetic energy via thermal energy. However, the conversion to workable kinetic energy via thermal energy constitutes wasted energy in relation to the required work of the pistons. In other words, because the energy source in the universe cannot be added to (first law), and energy is wasted through multiple thermal to kinetic energy transfers, and nothing can spontaneously heat itself (second law), if the source is not replenished the system will tend to maximum entropy and cease to function. Moreover, what must also be taken into consideration is how the wasted thermal energy in the conversion chain does damage to the material structure of the system itself-making it less efficient to convert energy. Entropy describes the observable irreversibility both of natural and technical systems, the passing away, deformation, and death of 'things', as well as the universe's own inevitable heat death, where 'every-thing' has passed away and 'no-thing remains'.

Whereas at the heart of Kant's reflective judgment lies the regulative assumption that nature functions as if purposive (teleological), the principle at the heart of Artaud's mode of reflection is entropic. Rather than permitting the taxonomical specification of nature, anarchic reflection takes as its point of departure the principle that at the heart of any reflection with actual things stands their inevitable decay. All reflection must, then, start with entropy as its self-regulating principle. The energetic system (be it organic or technical) that maintains the Form of things is also the condition of their inevitable destruction. To use an organic example, while oxygen and nutrients are necessary for mammalian life, their conversion to workable energy produces by-products that age and inevitably kill the same organism. Reflection with the actuality of life must, therefore, start from the standpoint of how life and death are bound to the same energetic system.

I have sought to show that while Artaud rejects Kant's determining judgment or scholastic judgments of quiddity, he does not reject judgment or the principle of haecceity in and of themselves. In fact, further into the notebooks, Artaud affirms a form of judgment that takes 'nutritive actuality [réalité nutritive]' as its point of departure. Artaud writes:

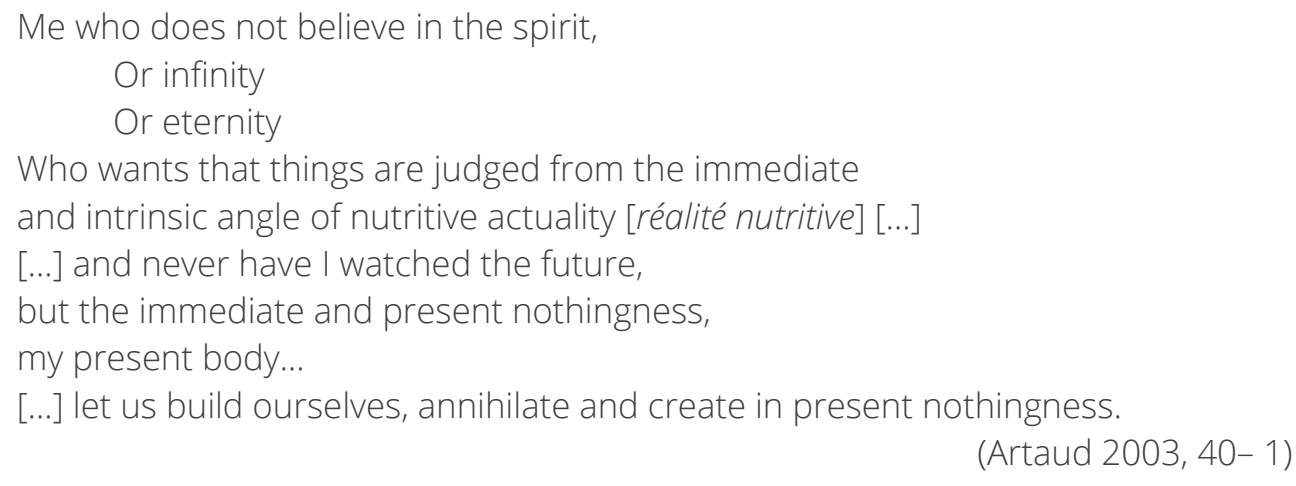

Not only is judgment present in this passage, but it is an explicitly reflective, immediate and intrinsic judgment that describes how the function of anarchic reflection operates philosophically. Similar to the sequence of Kantian reflective judgment, anarchic reflection proceeds from 'nutritive actuality' to conceptual or ontological indeterminacy and concludes in creative conceptual formation: 'let us build ourselves, annihilate and create in present nothingness'. 'Present 
nothingness', then, is the nutritive actuality of life that decomposes because it lives and lives because it decomposes. It is the presence of death in life and life in death. Anarchic reflective judgments on 'things' are judgments made concerning how particular things resist, but at the same time partake in, their own destruction. We build ourselves and create ourselves, but only insofar as this takes place within nutritive actuality. We build and create, but we also break and exhaust. Artaud's earlier affirmations that things must 'pass away' can be brought alongside 'present nothingness' and 'nutritive actuality' to produce a principle of haecceity that is likewise entropic: this is this and not that because its particular resistance to entropy individuates it so. The creative fight against the inevitably of decay bears its marks on individuality.

The entropic principle of reflection states that the energetic system that maintains the Form of things is also the condition of their inevitable destruction. Entropy likewise governs the task of the Theatre of Cruelty, since anarchic reflection's function is to energetically call into question/reflect with man's constitution (Form) in actuality (energeia). If, as Artaud states, the Theatre of Cruelty's task is to effectuate anarchic or energetic destruction, then it must manipulate the energetic system that maintains and destroys this constitution (Form). In a revealing passage from Artaud's 1936 Messages révolutionnaires, written two years prior to the publication of The Theatre and its Double, Artaud argues that to manipulate Formal energetic systems, energy's dynamism (thermodynamics) must be 'harnessed':

\footnotetext{
I wonder what would happen to the materialist conception [idée] when science, in its most recent development, teaches us that there is no matter, that all life is energy, and that matter, in its multiple forms, is nothing other than an expression of this energy.

Atoms are examined so that matter might be understood, but under the scrutiny of science each atom disappears and transforms into a particular version of the dynamism of energy. Human thought is also an energy which adopts forms. What then prevents us from viewing this energy through its particular form, and harnessing this intense source of energy? (Artaud 2007, 147)
}

If materialism becomes substantialised, as Artaud argues here, it becomes distorted into a philosophy of quiddity, where matter replaces abstract and conceptual 'whatness'. Whenever matter is abstracted in this way, it is conceived as the principle of things and no longer subject to deformation and decay. In contrast, what could be called actual-materialism, nutritive-materialism, or just actualism (based on Artaud's 'nutritive actuality', Kant's Wirklickheit and Aristotle's energeia) argues that life, matter, Form and thought should all be viewed and judged with respect to 'energy's dynamism'. From this angle, matter is only an expression of the 'atoms' that make it appear substantial, which, in turn, are only expressions of the energy that binds them together. Analogously, Form and thoughts that appear stable or substantial enough to determine what things are, are only expressions of stabilised energetic systems. Once the manipulation of Formal energetic systems is 'harnessed', Form's stabilisation and dissipation, or de-formation, become possible. The Theatre of Cruelty's task is to effectuate anarchic/energetic destruction of Form by manipulating its system of maintenance. 
Artaud names the system that maintains and stabilises Form's meaning, in the face of entropy, 'conformism':

\begin{abstract}
Far from accusing the crowds, or the public, we must blame the formal screen that we place between ourselves and the crowd; this form of new idolatry, the idolatry of fixed masterpieces, which is just one aspect of bourgeois conformism.

This conformism which makes us confuse the sublime, ideas, and things with the forms they have taken throughout time and in our minds-our snobbish, precious and aesthetic mentality —-the public no longer understands. (Artaud 1974, 57)
\end{abstract}

The notion of 'bourgeois conformism' has two mutual significations here. The first of these is relatively commonplace, defining the alignment of behaviours, beliefs and attitudes to particular social norms. This type of conformism sustains the second, more philosophical, sense, which refers to the holding together of Forms. This aligns with the aforementioned definition of anarchic reflection: an 'energetic system that maintains Form'. In Messages révolutionnaires, Artaud also writes that 'human thought is [...] energy which adopts forms' (Artaud 2007, 147). The task of conformism as the energetic system that holds Form together is to resist the entropy of Form. If Form and thought are to be understood energetically and in relation to the principle of entropy, then, like all energetic systems, specific measures are crucial for the continual cultivation, maintenance or conformism of this system. If the energy source is compromised, if the parts are reconfigured, or if it consumes and grows too quickly, then the system can reach a critical point and collapse. The task of the Theatre of Cruelty is to stimulate anarchic reflection, to produce a crisis in the system-anarchic destruction-so that Form can reach this critical point, collapse or be transformed. In other words, anarchic destruction is an energetic destruction of conformism. In the following paragraph from The Theatre and its Double, Artaud summarises this process:

\begin{abstract}
We must admit to ourselves that the purposiveness of an object, in its meaning and in the way that its natural form is used, is an affair of convention. [...] It is understood that a beautiful woman has a harmonious voice; however, if we were to have heard, for as long the world has been the world, all the beautiful women calling and greeting us with the sound of a trumpet or a trombone, we would have eternally associated the idea of a trumpet with the idea of a beautiful woman, and part of our internal vision of the world would have been radically transformed. We grasp through this that poetry is anarchic in as far as it reconfigures all of the relations between object and object and between form and their significations. It is anarchic in so far as its appearance is the consequence of a disorder that brings us closer to chaos. (Artaud 1974, 30)
\end{abstract}

The first half of this passage describes conformity or 'convention', arguing that the predicate 'harmonious voice' is, by convention alone, analytic of 'beautiful woman'. Only 'conformity' maintains the seemingly stable in this judgment. When conformity is anarchically/energetically destroyed, possibilities are opened for the relation between subjects and predicates and between 'form and their significations' to be 'radically transformed'. As Artaud states elsewhere, 'deformation is the principle of invention' (Artaud 1980, 253), and as seen in the previous passage, creative reconfiguration of these relations is anarchic poetry. The example that Artaud gives is the 
reconfiguration (of relations between subject and object and Form and its signification) of the harmonic woman, to the Form of woman with a trumpet for a mouth. The trumpet-mouthed woman is the anarchic poem. Anarchic poetry, therefore, takes place as the result of an energetic destruction of Form's conformism-a crisis of krisis-where it is no longer possible to judge determinately.

To be concise, the Theatre of Cruelty functions as anarchic reflection, which produces anarchic destruction (the energetic destruction of Form's conformism) which, in turn, generates the conditions by which anarchic poetry can take place. As I have argued, the principle that governs this process is entropy. Following the way in which Artaud describes anarchic reflection in his notebooks, it can be argued that anarchic reflection is the overarching process within which both anarchic destruction and anarchic poetry occur. Anarchic reflection effectuates both the energetic deformation of conformism and the subsequent formation of new configurations. The medium of this reflective movement is nutritive actuality (the actuality of the conforming, deforming and reforming of Form). All new configurations are, however, also subject to energetic deformation: nutritive actuality feeds itself of itself. In the Theatre of Cruelty, all Forms are dead stars reformed, entropic Ouroboroi.

At the end of the above passage from The Theatre and its Double, Artaud defines what he means by 'anarchic'. He writes that anarchic poetry is 'anarchic in so far as its appearance is the consequence of a disorder that brings us closer to chaos' (30). I argue that 'disorder' is synonymous with the entropic principle that governs anarchic reflection, and 'chaos' with the unmetered actuality of the conforming, deforming and reforming of Form. When the system of conformity is brought closer to the actuality of chaos, the crisis of krisis, or of judgment in general, ensues. Determinate predication is sacrificed to disorder as anarchic reflection reflects the chaos of actuality. As the beauty of harmony becomes the sublimity of chaos, the conformity of a woman's melodious voice is sacrificed to the chaotic blow of a trumpet.

The final part of this article compares the function of anarchic reflection to Kant's writings on the judgment of the feeling of the sublime from the third Critique. This involves exploring the counterpurposive nature of Kant's sublime and comparing it to the principle of entropy. Finally, I will describe how the sublime is conceived by Kant as a reflection with actuality (Wirklicheit), in a way that differs to judgments of beauty. I hope to show, in doing this, why Artaud's anarchic reflection is conceived of as an extension of Kantian sublimity qua a crisis of krisis.

In the third Critique, Kant explains that the judgment of the feeling of the sublime (in both its mathematical and dynamic forms) partakes of aesthetic judgment, and aesthetic judgment partakes of reflective judgment. Contrary, then, to determining judgments, the movement of reflection, as detailed above, moves from the entangled nature of nutritive actuality to conceptual indeterminacy, an indeterminacy that thereby makes the formation and transformation of empirical concepts attainable. The feeling of the sublime mirrors this movement of reflection. As 
Malcom Bowles writes, 'The non-determinative synthesis of the sublime is not decided upon, it is provoked' $(2000,10)$. For Bowles, the sublime is provoked by 'matter' (10). However, as Artaud argues, matter is only the expression of the energy that holds it together. Instead of matter, then, I argue that the sublime is provoked by actuality, an actuality that is entropic. Whereas the 'selfsufficient beauty of nature' (Kant 2000,129) operates in pure judgments of taste (the beautiful), and simultaneously excites our understanding and imagination into a pleasurable and harmonious play of purposiveness without purpose, the sublime moves from an actuality that is wild, devastating and contrapurposive:

\title{
there is so little that leads to particular objective principles and forms of nature corresponding to these that it is mostly rather in its chaos or in its wildest and most unruly disorder and devastation, if only it allows a glimpse of magnitude and might, that it excites the ideas of the sublime. (Kant 2000, 129-30)
}

The chaotic and unruly disorder at the heart of the sublime radically distinguishes it from the judgment of the feeling of beauty, which, although indeterminate, is a reflective judgment on the pleasure that harmonious Form excites between the imagination and the understanding. In the mathematical sublime, this great chaotic disorder, too large for imagination's representational capacity, 'awakens the feeling of a supersensible faculty in us' (Kant 2000,134). In other words, the idea of the sublime is mathematically excited when Reason, 'a faculty of the mind which surpasses every standard of sense' (138), is excited by the imagination's inability to capture actuality's disorderly contrapurposiveness. Like the mathematical sublime, the dynamic sublime excites the power of Reason when, from a position of safe distance, actuality's mighty disorderliness excites both powerlessness in the face of actuality and security in the capacity to judge Reason as independent of nature. While there is, therefore, a difference between the mathematical and dynamic sublime in Kant, both reflect (though from different reflexive proximities) on the chaotic, disorderly and contrapurposive quality of actuality; moreover, both reflect because of an inherent incapacity. Writing more explicitly about the difference between the feeling of beauty and sublimity, Kant argues how contrapurposiveness in Form is the most intrinsic quality distinguishing the two aesthetic judgments:

\begin{abstract}
The most important and intrinsic difference between the sublime and the beautiful, however, is this: that if, as is appropriate, we here consider first only the sublime in objects of nature (that in art is, after all, always restricted to the conditions of agreement with nature), natural beauty (the self-sufficient kind) carries with it a purposiveness in its form, through which the object seems as if it were to be predetermined for our power of judgment, and thus constitutes an object of satisfaction in itself, whereas that which, without any rationalizing, merely in apprehension, excites in us the feeling of the sublime, may to be sure appear in its form to be contrapurposive for our power of judgment, unsuitable for our faculty of presentation, and as it were doing violence to our imagination, but is nevertheless judged all the more sublime for that. (Kant 2000, 129)
\end{abstract}

For Kant, 'Beauty', therefore, carries with it a purposiveness in Form whereby the 'object' that is deemed beautiful appears as though it is predetermined for the factuality of the understanding. 
In contrast, the sublime has a 'contrapurposive' principle at the centre of its reflective judgment that is 'unsuitable' for both sensible presentation and conceptual understanding. As Bowles continues to write of the sublime, 'It is forced out of us through the collapse of the understanding' (10).

This devastating, disorderly and chaotic non-teleological principle is comparable, perhaps even equivalent, to the principle of entropy. It commits violence to the unifying power of the imagination, opening up an agonising window onto the chaos of actuality that pushes the possibility of judgment to the very edge of what is criticisable. Moreover, the sublime is felt 'only by means of a momentary inhibition followed by a stronger outpouring of the vital force.' Life, therefore, accompanies the sublime at the edge of the crisis of krisis (Kant 2000,111). Where there is devastation and disorder, life follows. The sublime reunites us with the entropic principle that states that life is not some harmonious Form purposively and mechanically designed for our delight, but the consequence of death.

While Artaud only refers to the sublime a handful of times in the Theatre and its Double, the accompanying notes and manuscripts used to produce the book suggest that anarchic destruction and anarchic poetry, hence anarchic reflection, are closely linked to the feeling of the sublime. For example, in 1936 Artaud writes in his notes for the preface, 'Beneath all this, poetry remains a diffuse idea of the sublime, only discernible under an overwhelming aspect. There is something sublime in certain natural catastrophes; earthquakes, volcanic eruptions, cracks in the sea bed, excessive numbers of collisions, planes crashing in flames, railway disasters' (Artaud 1974, 159). Taking into consideration the difference between the Kantian mathematical and dynamic sublime, the intentional staging of anarchic poetry that effectuates a crisis of krisis (a crisis that is both painful and pleasurable, both destructive and poetic, both fatal and vital) defines the Theatre of Cruelty as cruel. As Artaud writes:

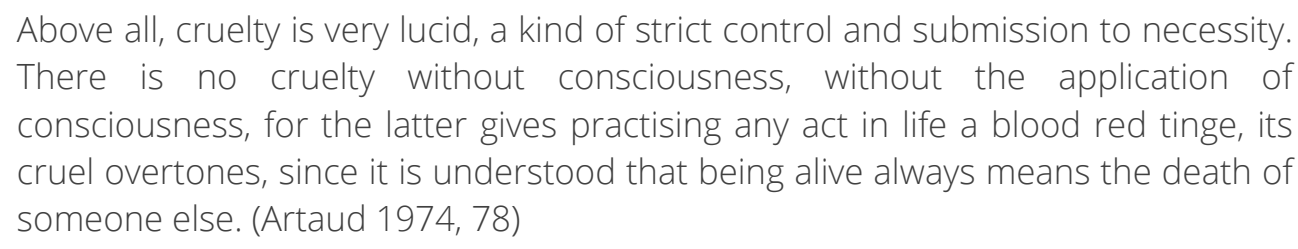

The 'overwhelming' and 'catastrophic' aspect of anarchic poetry, but more importantly, the intentional or conscious staging of it, is that which is cruel in the Theatre of Cruelty. To energetically break the Form of conformism, the pain of the contrapurposive nature of deformation must be invoked. Rather than being at a safe distance from the catastrophe of Form, in the Theatre of Cruelty, the contrapurposive quality of actuality's disorder surrounds and overwhelms all those that participate in it, provoking a crisis of krisis. In the Theatre of Cruelty, you do not watch the plane crash, you are in the plane crash. Rather than pure nihilistic destruction, it must be understood that life is only possible because of the actual 'death of someone else.' In the Theatre of Cruelty, life's possibility is bound to death's actuality and the possibility of death to actual life. 


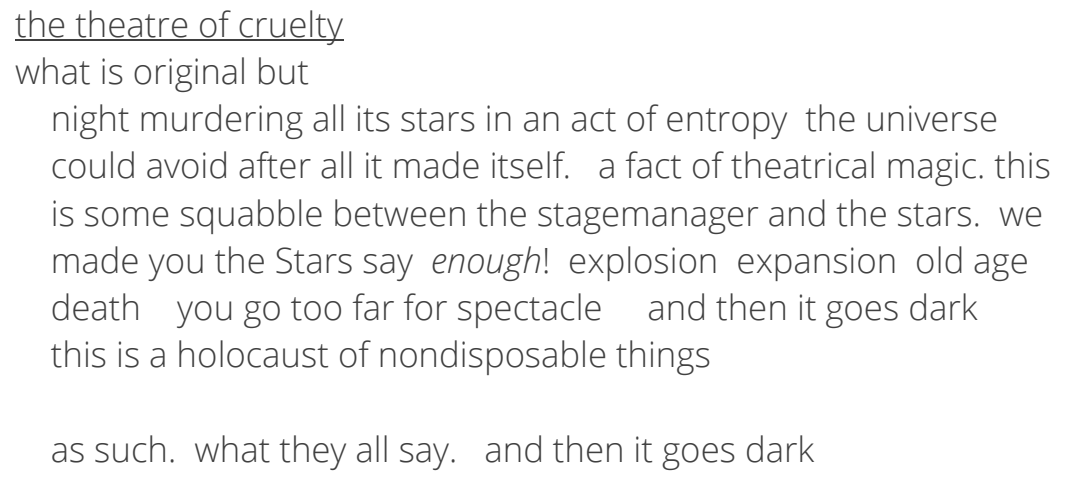

(Mor, 2015)

\section{Notes}

\footnotetext{
${ }^{1}$ Thévenin, in her 1969 Tel quel article, 'Entendre/Noir/Lire', accuses Deleuze of the same inconsiderateness as Lotringer, writing that 'Deleuze falls into the major trap of identifying Artaud as a schizophrenic' (37).

2 For example, Stephan Barber (1993), Florence de Mèredieu (2006) and David Shafer (2016).

${ }^{3}$ Unsurprisingly, the latest translation in English concerns this episode of Artaud's life (Artaud 2018).

${ }^{4}$ While Kélina Gotman (2015) has written on Artaud and judgment, there is little analysis of the Kantian connection to Artaud. Howard Caygill's presentation (2013) 'The Folly of Speculation' is the only piece of work that compares Kant and Artaud. However, this comparison does not discuss judgment, sublimity or cruelty in any detail.

${ }^{5}$ The work presented here on actuality and réalité is indebted to Nathaniel Wooding.

${ }^{6}$ While Artaud quotes Bergson (Artaud 1980), it is difficult to determine which texts he has read. I suspect Time and Free Will: An Essay on the Immediate Data of Consciousness and Mind-Energy.

7 This is not far from Laura Cull Ó Maoilearca's immanent theatre, Theatres of Immanence: Deleuze and the Ethics of Performance (2012)
}

\section{Works Cited}

Artaud, Antonin. 2018. Artaud 1937 Apocalypse: Letters from Ireland by Antonin Artaud. Translated and edited by Stephen Barber. London: Infinity Land.

-_- 1974. Collected Works of Antonin Artaud. Vol. 4. London: Calder and Boyars.

2007. Messages révolutionnaires. Paris: Gallimard.

2004. Euvres. Paris: Gaillimard.

_-_. 2003. Euvres complètes XXVI. Paris: Gallimard.

1980. Euvres complètes VIII: De Quelques problèmes d'actualité aux messages révolutionnaires. Paris: Gallimard.

Barber, Stephan. 1993. Antonin Artaud: Blows and Bombs. Faber and Faber: London.

Barthes, Roland. 1995. Euvres completes III. Paris: Seuil.

Budd, Michael. 2000. 'Kant and the Provocation of Matter'. The Matter of Critique. Edited by Andrea Rehberg and Rachel Jones. Manchester: Clinamen.

Caygill, Howard. 2015. 'Artaud-Immunity: Derrida and the Mômo'. Derrida Today 8 (2): 113-135. 
2013. 'The Folly of Speculation'. Presented at 'Speculative Thinking in Art, Literature, and Philosophy', Haus der Kulturen der Welt, Tuesday, May 21.

Clausius, Rudolf. 1867. The Mechanical Theory of Heat, with its applications to the steam-engine and to the physical properties of bodies. Translated by John Tyndall. Edited by T. Archer Hirst. London: John Van Voorst. https://doi.org/10.1080/14786445608642141

___. 2009 (1856). 'On a modified form of the second fundamental theorem in the mechanical theory of heat'. The London, Edinburgh, and Dublin Philosophical Magazine and Journal of Science 12 (77): 81-98.

Derrida, Jacques, Peggy Kamuf, and Kaira Marie Cabañas. 2017. Artaud the Moma: interjections of appeal. New York: Columbia University Press.

Derrida, Jacques. 2017. Writing and Difference. Chicago: University of Chicago Press.

Foucault, Michel. 2001. 'The Discourse on Language'. In Critical Theory Since 1965. Edited by Adams, Hazard, and Leroy Searle, 148-162. Tallahassee: Florida State University Press.

_-_. 2006. Madness and Civilization: A History of Insanity in the Age of Reason. New York: Vintage.

Gotman, Kélina. 2015. 'Exceptionalism, Schizophrenia, Artaud: On Judgment.' Performance Philosophy 1: 119-25. https://doi.org/10.21476/PP.2015.1121

Guyer, Paul. 1990. 'Reason and Reflective Judgment: Kant on the Significance of Systematicity'. Noûs 24 (1): 17-43. https://doi.org/10.2307/2215611

Kant, Immanuel, and Paul Guyer. 2009. Critique of Pure Reason. Cambridge: Cambridge University Press.

Kant, Immanuel. 2000. The Cambridge Edition of the Works of Immanuel Kant: Critique of the Power of Judgment. Cambridge: Cambridge University Press.

_-_. 2002. The Cambridge Edition of the Works of Immanuel Kant: Theoretical Philosophy after 1781. Cambridge: Cambridge University Press.

Kirkkopelto, Esa. 2015. 'For What Do We Need Performance Philosophy'. Performance Philosophy 1: 4-6. https://doi.org/10.21476/PP.2015.117

Lotringer, Sylvere, and Joanna Spinks. 2015. Mad like Artaud. Minneapolis, MN: Univocal.

Mèredieu, Florence de. 2006. C'était Antonin Artaud. Paris: Fayard.

Mor, Barbara. 2012. 'The Theatre of Cruelty'. CTheory. https://journals.uvic.ca/index.php/ctheory/article/view/14937/5832

Murray, Ros. 2014. Antonin Artaud: The Scum of the Soul. Basingstoke: Palgrave Macmillan.

Preciado, Paul. 2013. Testo Junkie. Translated by Bruce Benderson. New York: Feminist Press.

Shafer, David. 2016. Antonin Artaud: Critical Lives. London: Reaktion Books.

Sollers, Philippe. 2011. Discours parfait. Paris: Gallimard.

Thévenin, Paule. 1969-1970. 'Entendre/voir/lire'. Tel Quel 39-40.

\section{Biography}

Joel White is a Doctoral Candidate in the French Department at King's College London.

(c) 2018 Joel White 